\title{
Optimalisasi Intensitas Cahaya pada Luas Permukaan Solar Cell
}

\author{
Hilmansyah $^{1^{*}}$, Ramli ${ }^{2}$ \\ ${ }^{1,2}$ Politeknik Negeri Balikpapan \\ *Hilmansyah555@gmail.com
}

\begin{abstract}
Optimization of power at the output of the solar cell by Surface, Intensity and Wavelength of Light to determine the effect of light intensity, the surface area of the solar cell, and the wavelength of the light filter on the output power generated by the solar cell. Can be used two Solar-cell, each of which has a size of $5 \mathrm{~cm} \times 2.4$ $\mathrm{cm}$ and $5 \mathrm{~cm} \times 5 \mathrm{~cm}$. With an input voltage of $1.8 \mathrm{~V} 2.00 \mathrm{~V}$ and $2.4 \mathrm{~V}$ so as to produce different light intensities. solar cell mounted light filters of red, yellow and blue because it shows that, for all kinds of filters and diesel obtained value of the output power increases. This is due to the greater value given input voltage in the circuit.
\end{abstract}

Keywords : solar-cell output power (output), light intensity

Abstrak

Optimalisasi daya pada keluaran pada solar-cell oleh Luas Permukaan, Intensitas dan Panjang Gelombang Cahaya untuk mengetahui pengaruh intensitas cahaya, luas permukaan solar cell, dan panjang gelombang filter cahaya terhadap daya keluaran yang dihasilkan oleh solar cell. Dapat di gunakan dua buah Solar-cell yang masing-masing memiliki ukuran $5 \mathrm{~cm}$ x 2,4 $\mathrm{cm}$ dan $5 \mathrm{~cm}$ x $5 \mathrm{~cm}$. Dengan tegangan input sebesar $1,8 \mathrm{~V} 2,00 \mathrm{~V}$ dan 2,4 V sehingga menghasilkan intensitas cahaya berbeda-beda. solar cell dipasang filter cahaya merah, kuning dan biru oleh karena hal tersebut diperoleh bahwa untuk semua jenis filter dan jenis solar diperoleh nilai daya keluaran yang semakin besar. Hal ini disebabkan karena semakin besar nilai tegangan input yang diberikan dalam rangkaian.

Kata kunci: solar-cell daya keluaran, intensitas cahaya

\section{Pendahuluan}

Pulau Kalimantan sangat berpotensi untuk menjadikan sel surya sebagai salah satu sumber energi masa depan mengingat posisi Kalimantan pada garis khatulistiwa yang memungkinkan sinar matahari dapat optimal diterima di hampir seluruh kalimantan sepanjang tahun. Dalam kondisi puncak atau posisi matahari tegak lurus, sinar matahari yang jatuh di permukaan panel surya di Kalimantan seluas satu meter persegi akan mampu mencapai 900 hingga 1000 watt. Bahkan, total intensitas penyinaran perharinya Kalimantan mampu mencapai 4500 watt hour per meter persegi yang membuat Kalimantan tergolong kaya sumber energi matahari. Dengan letaknya di daerah katulistiwa, matahari di Kalimantan mampu bersinar hingga 2.000 jam per tahunnya. Di sisi lain, topografi dan geografi wilayah Kalimantan tidak memungkinkan kebutuhan listrik dipenuhi melalui jaringan.[1]

Oleh karena itu, tenaga energi surya diolah sedemikian rupa sehingga dapat menghasilkan daya listik yang biasa disebut dengan solar sel yang merupakan energi terbarukan.[2]

\subsection{Photovoltaic}

Photovoltaic mengkonversi cahaya menjadi listrik. Alat ini lebih dikenal dengan solar sel. Solar sel dapat menyimpan paket energi cahaya menjadi energi listrik. Solar-sel dipengaruhi oleh dua hal. Banyaknya intensitas cahaya yang 
masuk serta luasan solar-sel tersebut. Semakin besar intensitas yang masuk ke dalam solar sel maka semakin besar pula daya yang dihasilkannya. Semakin luas permukaan solar-sel, maka semakin besar pula daya listrik yang dihasilkannya. [2]

Dengan semakin berkembangnya tekhnologi, para ilmuwan akhirnya memikirkan bagaimana caranya untuk memanfaatkan tenaga surya. Dengan mengacu pada prinsip dasar dari photovoltaic yang mengubah cahaya menjadi energi listrik, maka Efek fotovoltaik ini pertama kali dikaji dan diakui pada tahun 1839 oleh fisikawan prancis AE Becquerel. Pada tahun 1883 charles fritts membuat Fotovoltaik cell, tetapi alat ini tidak bisa maksimal.dan pada akhirnya pada tahun 1905 Albert Einstein menjelaskan efek fotolistrik dan mematenkan Solar-cell pertamanya pada tahun 1946. waktu itu Albert Einstein masih bekerja pada sebuah industri yang menghasilkan transistor.[2]

Pada tahun 1954 Sel fotovoltaik modern dikembangkan di Bell Laboratories yang sangat efisien pertama kali dikembangkan oleh Daryl Chapin, Calvin Fuller Souther dan Gerald Pearson pada tahun 1954 menggunakan silikon tersebar PN junction. Di era tersebut Sel dikembangkan untuk mainan dan menggunakan kecil lainnya, sekarang rumahan maupun pabrikan di dunia mulai menggunakan Solar-Cell. Bentuk tampilan solar cell yaitu :

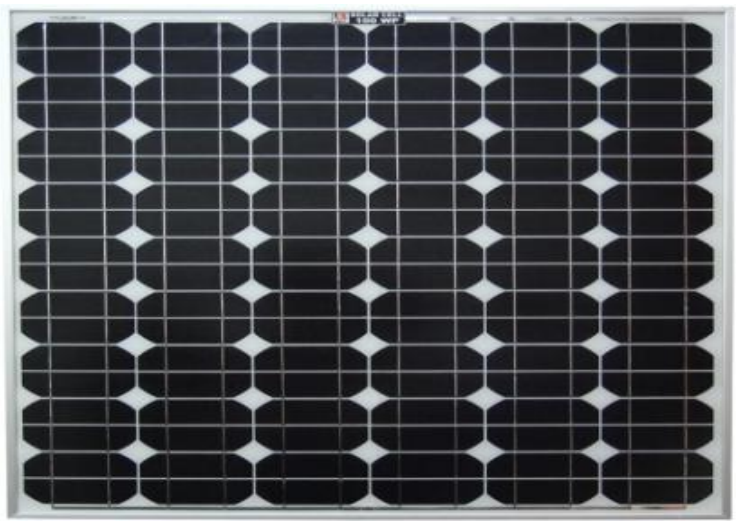

Gambar 1. Solar-cell

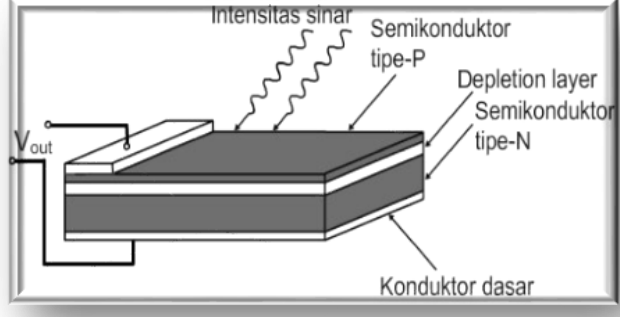

Gambar 2. Cara mengukur tegangan pada rangakaian fotovoltaic

Solar cell terbuat dari bahan semikonduktor contohnya: silicon, cadmium sullphide, gallium arsenida dan selenium. [3]

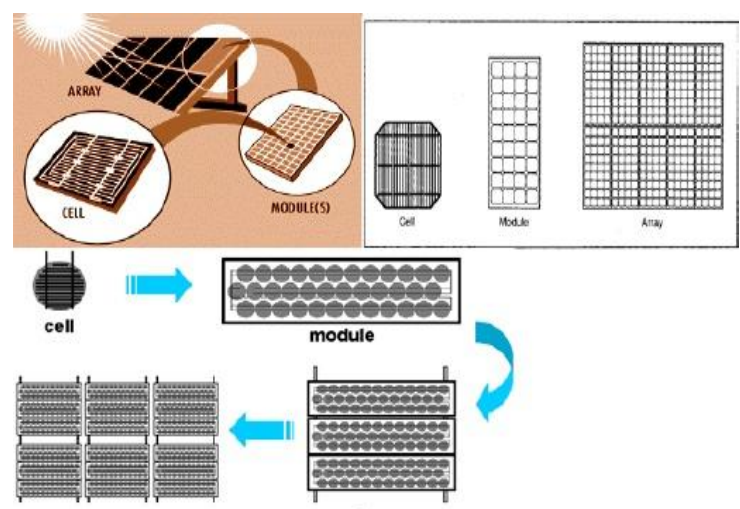

Gambar 3. Prinsip kerja solar sel

Dimana cahaya matahari ditangkap oleh bidang solar sel kemudian ditampung dan selanjutnya mengubah atau mengkonversi energi dari radiasi matahari menjadi energi listrik. Beberapa komponen yang digunakan adalah elemen semikonduktor yang disebut sel surya, kemudian disusun menjadi modul surya.[2]

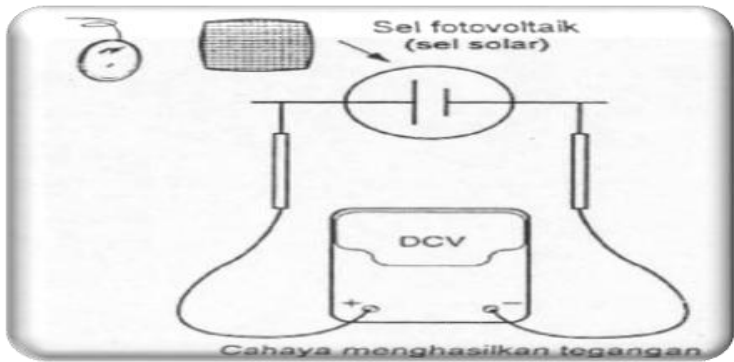

Gambar 3. Penampang melintang solar-cell

Defletion layer adalah pertemuan antara subtra tipe $\mathrm{P}$ dan substrat tipe $\mathrm{N}$. 
Pada sambungan $p$ - $n$ inilah terjadi proses konversi cahaya matahari menjadi energi listrik. Untuk keperluan sel surya, semikonduktor $n$ berada pada lapisan atas sambungan $p$ yang menghadap kearah datangnya cahaya matahari, dan dibuat jauh lebih tipis dari semikonduktor $p$, sehingga cahaya matahari yang jatuh ke permukaan sel surya dapat terus terserap dan masuk ke daerah deplesi dan semikonduktor $p[4]$.

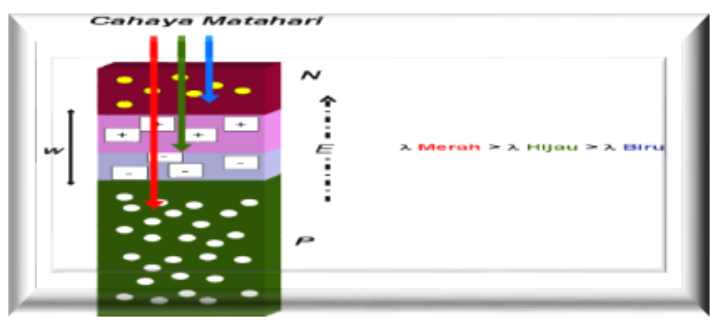

Gambar 4. Sambungan PN pada solar cell

Ketika sambungan semikonduktor ini terkena cahaya matahari, maka elektron mendapat energi dari cahaya matahari untuk melepaskan dirinya dari semikonduktor $n$, daerah deplesi maupun semikonduktor. Terlepasnya elektron ini meninggalkan hole pada daerah yang ditinggalkan oleh elektron yang disebut dengan fotogenerasi elektron-hole (electron-hole photogeneration) yakni, terbentuknya pasangan elektron dan hole akibat cahaya matahari. Cahaya matahari dengan panjang gelombang (dilambangkan dengan simbol "lambda" sebagaimana di gambar atas ) yang berbeda, membuat fotogenerasi pada sambungan $P N$ berada pada bagian sambungan $P N$ yang berbeda pula. Spektrum merah dari cahaya matahari yang memiliki panjang gelombang lebih panjang, mampu menembus daerah deplesi hingga terserap di semikonduktor $p$ yang akhirnya menghasilkan proses fotogenerasi di sana. Spektrum biru dengan panjang gelombang yang jauh lebih pendek hanya terserap di daerah semikonduktor $n$. Selanjutnya, dikarenakan pada sambungan $P N$ terdapat medan listrik $E$, elektron hasil fotogenerasi tertarik ke arah semikonduktor $n$, begitu pula dengan hole yang tertarik ke arah semikonduktor $p$. Apabila rangkaian kabel dihubungkan ke dua bagian semikonduktor, maka elektron akan mengalir melalui kabel. Jika sebuah lampu kecil dihubungkan ke kabel, lampu tersebut menyala dikarenakan mendapat arus listrik, dimana arus listrik ini timbul akibat pergerakan elektron. Solar sel dapat menyimpan paket energi cahaya menjadi energi listrik. Solar-sel dipengaruhi oleh dua hal. Banyaknya intensitas cahaya yang masuk serta luasan solar-sel tersebut. Semakin besar intensitas yang masuk ke dalam solar sel maka semakin besar pula daya yang dihasilkannya. Semakin luas permukaan solar-sel, maka semakin besar pula daya listrik yang dihasilkannya. Intensitas cahaya adalah besaran pokok fisika untuk mengukur daya yang dipancarkan oleh suatu sumber cahaya pada arah tertentu per satuan sudut.

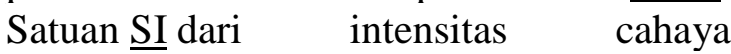
adalah $\underline{\text { Candela }}(\mathrm{Cd})$. Kemampuan mata manusia hanya sensitif dan dapat melihat cahaya dengan panjang gelombang tertentu (spektrum cahaya nampak) yang diukur dalam besaran pokok ini. Pada sel surya terdapat sambungan (junction ) antara dua lapisan tipis yang terbuat dari bahan semikonduktor yang masing-masing diketahui sebagai semikonduktor jenis "P" (positif) dan semikonduktor jenis " $\mathrm{N}$ " (negatif). Semikonduktor jenis-N dibuat dari kristal silikon dan terdapat juga sejumlah material lain ( umumnya posfor ) dalam batasan bahwa material tersebut dapat memberikan suatu kelebihan elektron bebas. Elektron adalah partikel sub atom yang bermuatan negatif, sehingga silikon paduan dalam hal ini disebut sebagai semikonduktor jenis-N (Negatif). Semikonduktor jenis-P juga terbuat dari kristal silikon yang didalamnya terdapat sejumlah kecil materi lain (umumnya boron) yang mana menyebabkan material tersebut kekurangan satu elektron bebas. Kekurangan atau hilangnya elektron ini disebut lubang (hole). Karena tidak ada 
atau kurangnya elektron yang bermuatan listrik negatif maka silikon paduan dalam hal ini sebagai semikonduktor jenis-P (Positif). Susunan sebuah solar cell, sama dengan sebuah dioda, terdiri dari dua lapisan yang dinamakan PN juction. PN junction itu diperoleh dengan jalan menodai sebatang bahan semikonduktor silikon murni (valensinya 4) dengan impuriti yang bervalensi 3 pada bagian sebelah kiri, dan yang di sebelah kanan dinodai dengan impuriti bervalensi 5 . Meskipun spektrum optik adalah spektrum yang kontinu sehingga tidak ada batas yang jelas antara satu warna dengan warna lainnya, tabel berikut memberikan batas kira-kira untuk warna-warna spectrum[5] :

Tabel 1. Daftar panjang gelombang spektrum warna

\begin{tabular}{|c|c|}
\hline Spektrum Warna & $\boldsymbol{\lambda} \mathbf{( n m )}$ \\
\hline Merah & $620-750$ \\
\hline Jingga & $590-620$ \\
\hline Kuning & $570-590$ \\
\hline Hijau & $495-570$ \\
\hline Biru & $450-495$ \\
\hline Nila & $420-450$ \\
\hline Ungu & $380-450$ \\
\hline
\end{tabular}

\section{Metoda Penelitian}

Pada penelitian dilakukan dengan menggunakan 2 jenis solar cell yang berbeda yakni solar cell dengan ukuran $(5 \times 2,4) \mathrm{cm}$ dan $(5 \times 5) \mathrm{cm}$. bengan tujuan untuk membandingkan luas permukaan solar cell dengan daya keluarannya. Pada masing-masing solar cell diberikan tegangan input dengan variasi 1,80 volt, 2,00 volt, dan 2,50 volt untuk mengetahui pengaruh tegangan input terhadap daya keluaran. Dalam hal ini daya keluaran diperoleh melalui pengukuran tegangan output dan arus output. Untuk masingmasing pengukuran dilakukan sebanyak tiga kali pengulangan. Rangkaian percobaan dipasang 3 jenis filter yang berbeda yakni merah, kuning dan biru untuk membanding dan mengetahui pengaruh panjang gelombang masingmasing filter terhadap daya keluaran dari solar cell. Dari Data tegangan input dan daya rata-rata yang ada akan diolah hingga memperoleh grafik dan persamaan regresinya.[6]

\section{Hasil Penelitian}

Data yang diperoleh dari hasil percobaan sebagai berikut :

Tabel 2. Pengaruh tegangan input terhadap daya keluaran

\begin{tabular}{|c|c|c|c|c|c|}
\hline $\begin{array}{l}\text { jenis } \\
\text { solar }\end{array}$ & Filter & Vin & $\begin{array}{l}\text { Vout } \\
\text { Rerata }\end{array}$ & $\begin{array}{l}\text { Iout } \\
\text { Rerata }\end{array}$ & $\begin{array}{l}\text { Pout } \\
\text { Rerata }\end{array}$ \\
\hline \multirow[t]{9}{*}{1} & \multirow[t]{3}{*}{ M } & 1.80 & 0.48 & 3.38 & 1.63 \\
\hline & & 2.00 & 0.60 & 24.43 & 14.66 \\
\hline & & 2.50 & 0.60 & 53.66 & 32.20 \\
\hline & \multirow[t]{3}{*}{$\mathrm{K}$} & 1.80 & 0.48 & 14.23 & 6.87 \\
\hline & & 2.00 & 0.50 & 21.00 & 10.50 \\
\hline & & 2.50 & 0.60 & 40.33 & 24.19 \\
\hline & \multirow[t]{3}{*}{ B } & 1.80 & 0.46 & 12.51 & 5.84 \\
\hline & & 2.00 & 0.50 & 19.00 & 9.50 \\
\hline & & 2.50 & 0.60 & 31.66 & 19.00 \\
\hline \multirow[t]{9}{*}{2} & \multirow[t]{3}{*}{ M } & 1.80 & 0.50 & 11.60 & 5.80 \\
\hline & & 2.00 & 0.60 & 15.83 & 9.49 \\
\hline & & 2.50 & 0.60 & 31.00 & 18.60 \\
\hline & \multirow[t]{3}{*}{ K } & 1.80 & 0.50 & 7.56 & 3.78 \\
\hline & & 2.00 & 0.51 & 12.60 & 6.51 \\
\hline & & 2.50 & 0.60 & 24.33 & 14.59 \\
\hline & \multirow[t]{3}{*}{ B } & 1.80 & 0.50 & 6.76 & 3.38 \\
\hline & & 2.00 & 0.51 & 10.83 & 5.59 \\
\hline & & 2.50 & 0.60 & 23.00 & 13.80 \\
\hline
\end{tabular}




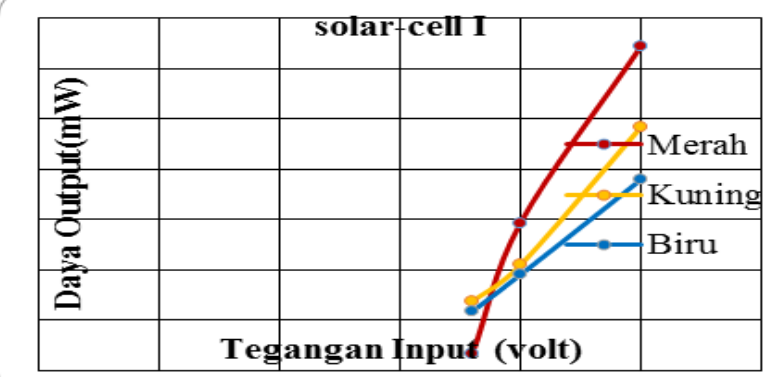

Gambar 7. Grafik hubungan tegangan input terhadap daya output pada solar-cell I.

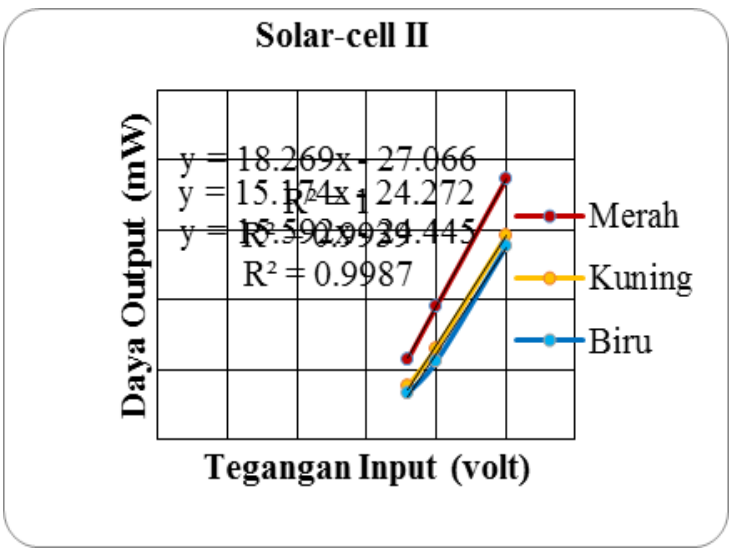

Gambar 8. Grafik hubungan tegangan input terhadap daya output pada solar-cell II

Berdasarkan hasil percobaan dalam tabel 2 dan dari kedua grafik diketahui bahwa untuk semua jenis filter dan jenis solar diperoleh nilai daya keluaran yang semakin besar. Hal ini disebabkan karena semakin besar nilai tegangan input yang diberikan dalam rangkaian maka semakin besar [6]pula intensitas cahaya yang dihasilkan. Akibatnya daya keluaran yang dihasilkan dari solar cell juga semakin besar. Dalam hal ini, tegangan input merupakan indikator dari intensitas cahaya. Hal didasarkan karena tegangan input adalah tegangan yang berasal dari power supply yang diberikan kepada lighting module sebagai sumber cahaya untuk solar-sell, sehingga semakin besar nilai tegangan input yang diberikan maka nyala lampu semakin terang akibatnya intensitas cahayamenjadi semakin besar.[3]

Jika membandingkan daya keluaran kedua jenis solar sell maka secara teori diketahui bahwa semakin besar luas penampang solar cell maka semakin besar daya keluaran untuk semua jenis filter. Hal ini disebabkan karena semakin luas penampang solar cell maka semakin banyak elektron yang dihasilkan dari proses fotogenerasi. Proses fotogenerasi adalah proses terlepasnya elektron pada semikonduktor tipe $\mathrm{n}$ karena mendapat cahaya dengan intensitas tertentu. Dengan semakin besarnya pergerakan elektron dalam medan listrik maka arus keluaran yang terukur juga semakin besar. Akibatnya daya ouput yang dihasilkan juga tentu semakin besar. Akan tetapi, hal ini jauh berbeda dari hasil percobaan yang diperoleh. Ha ini disebabkan karena ketidaktelitian dalam membaca skala pada alat ukur. [6]

Ketiga jenis filter diketahui bahwa secara teori, semakin besar panjang gelombang maka semakin kecil frekuensinya. Akibatnya intensitas cahaya yang dihasilkan menjadi semakin kecil pula. Sebaliknya, semakin kecil panjang gelombang maka semakin besar frekuensinya dan semakin besar pula intensitas cahanya. Hal ini menjadi landasan untama mengenai pengaruh filter ketiga warna yang digunakan. Atau dapat dibandingkan bahwa $\lambda$ merah $>\lambda$ kuning $>$ $\lambda$ biru, maka nilai frekuensinya berbanding terbalik dan $I$ merah $<I$ kuning $<I$ biru, dimana $\mathrm{P}$ merah $<\mathrm{P}$ kuning $<\mathrm{P}$ biru. [7]

\section{Kesimpulan}

Nilai panjang gelombang, $\lambda$ merah $>$ $\lambda$ kuning $>\lambda$ biru dan nilai frekuensi masing-masing warna, $f$ merah $<f$ kuning $<$ $f$ biru.Semakin besar intensitas cahaya maka semakin besar pula daya yang dihasilkan oleh solar sel sehingga besar luas solar-sel maka semakin besar pula daya yang dihasilkannya, sebaliknya semakin kecil luas solar-sel maka semakin kecil pula daya listrik yang dihasilkannya dan besar panjang gelombang cahaya yang masuk ke solar-sel maka semakin kecil 
daya listrik yang dihasilkannya, sebaliknya bila panjang gelombang yang masuk semakin kecil maka daya listrik yang dihasilkan solar-sel akan semakin besar.

\section{Saran}

Pengukuran data dapat dilakukan dengan menggunakan ukuran solar sell yang lebih besar dari $5 \mathrm{~cm} \times 2,4 \mathrm{~cm}$ agar daya yang dihasilkan lebih besar sesuai dengan kebutuhan.

\section{Daftar Pustaka}

[1] M. A. Green, "Limits on the open- circuit voltage and efficiency of silicon solar cells imposed by intrinsic Auger processes", IEEE Trans. Electron Devices, vol. 31, no. 5, pp. 671-678, May 1984.

[2] M. J. McCann, K. R. Catchpole, K. J. Weber, A. W. Blakers, "A review of thin-film crystalline silicon for solar cell applications. Part 1: native substrates", Solar Energy Mater. Solar Cells, vol. 68, pp. 135-171, 2001.

[3] G. P. Willeke, "Thin crystalline silicon solar cells", Solar Energy Mater. Solar Cells, vol. 72, pp. 191-200, 2002.

[4] X. F. Brun, S. N. Melkote, "Analysis of stresses and breakage of crystalline silicon wafers during handling and transport", Solar Energy Mater. Solar Cells, vol. 93, pp. 12381247, 2009.

[5] A. Schneider, C. Gernards, P. Fath, E. Bucher, R. J. S. Young, J. A. Raby, A. F. Carroll, "Bow reducing factors for thin screenprinted $\mathrm{mc}-\mathrm{Si}$ solar cells with Al BSF", Proc. 29th IEEE Photovoltaic Spec. Conf., pp. 336-339, 2002.

[6] T. Dullweber, S. Gatz, H. Hannebauer, T. Falcon, R. Hesse, J. Schmidt, R. Brendel, "Towards $20 \%$ efficient large-area screenprinted rear-passivated silicon solar cells", Progress Photovoltaics: Res. Appl., vol. 20, no. 6, pp. 630638, 2011.

[7] G. Dingemans, W. M. M. Kessels, " Status and prospects of $A l \backslash \$ \_\left\{2 \lambda \$ O \backslash \$ \_\{3 \wedge \$ \text { - }\right.$ based surface passivation schemes for silicon solar cells ",J. Vacuum Sci. Technol. A: Vacuum Surfaces Films, vol. 30, pp. 0408021-040802-27, 2012. 